\title{
ANALISA PENGEMBANGAN MIKRO EKONOMI SYARIAH BERBASIS \\ PEMBERDAYAAN PEREMPUAN DAN RUMAH TANGGA
}

Oleh : Neneng Munazah, Zulkarnain Lubis

Dosen tetap Prodi Perbankan Syariah FAI Universitas Islam Assyafiiyah

Email : nenengmunajah,fai@uia.ac.id , zulkarnain_lubis07@yahoo.com

\section{ABSTRAK}

Terjadinya krisis moneter dari ekonomi yang menimpa Indonesia memberikan banyak pelajaran berharga, salahsatunya adalah dengan mempersiapkan pemberdayaan perempuan dan keluarga dalam hal sebagai masyarakat yang produktif dan berdaya secara ekonomi, sehingga menjadi suatu lapisan yang akan tangguh mandiri ketika terjadi gelombang krisis ekonomi dan keuangan baik sekala nasional maupun global. Peradaban yang unggul adalah peradaban yang kuat dalam berbagai aspek kehidupan suatu masyarakat, bangsa dan negara. Dimana berbagai aspek - aspek kehidupan Ekonomi, Pendidikan, Budaya, Kesejahteraan, Kesehatan, Hukum dan Keadilan, Keamanan dan kekuatan angkatan bersenjata mencapai puncak kemandirian, kuat dan terdepan.

Bagaimana suatu masyarakat, bangsa dan negara bisa mencapai keunggulan berbagai aspek kehidupan tersebut di atas salah satu indikator yang menjadi fokus pembangunan dan pengembangan adalah mempersiapkan manusianya.

Salah satu cara mempersiapkan manusia masa depan adalah dengan memperhatikan secara fokus dan serius pada sisi pemberdayaan perempuan dan keluarga.

Dalam hal ini Kaum perempuan, Karena Perilaku Kaum Wanita bisa menjadi indikator atau tolak ukur Kemajuan, Peradaban Suatu bangsa

Kemudian bagaimana mewujudkan suatu bangsa itu Kuat, Maju. Beradab dan Unggul dalam dunia sekarang ini dengan kemandirian ekonomi Islam (Syariah) di sektor Mikro berbasis wanita dan keluarga.

Kata Kunci : Mikro ekonomi syariah, Pemberdayaan, Perempuan dan Keluarga 


\section{A. LATAR BELAKANG MASALAH}

Dampak buruk jika terjadi krisis ekonomi baik secara nasional atau pun global adalah hancurnya sendi-sendi kehidupan masyarakat umum, baik secara stabilitas ekonomi keluarga, sesial budaya kehidupan masyarakat masyarakat, tingkat kesehatan dan kesejahteraan masyarakat yang rendah, serta keterbelakangan pendidikan.

Dapat di bayangkan jika ini terjadi dalam waktu yang tidak sebentar, maka akan ada satu entitas penduduk yang sangat memperihatinkan.

Perlu disyukuri, pada saat masyarakat dan bangsa Indonesia, khususnya kaum muslimin mengalami krisis berbagai bidang kehidupan, khususnya dalam bidang ekonomi, terdapat kesadaran transcendental untuk mengembalikan persoalan ini pada ajaran Islam. Meskipun pada mulanya ajaran Islam dalam bidang ekonomi dianggap sebagai alternatif, akan tetapi secara bertahap diharapkan menjadi satu-satunya pilihan.

Terjadinya krisis moneter dari ekonomi yang menimpa Indonesia memberikan banyak pelajaran berharga, salahsatunya adalah dengan mempersiapkan pemberdayaan perempuan dan keluarga dalam hal sebagai masyarakat yang produktif dan berdaya secara ekonomi, sehingga menjadi suatu lapisan yang akan tangguh mandiri ketika terjadi gelombang krisis ekonomi dan keuangan baik sekala nasional maupun global Peradaban yang unggul adalah peradaban yang kuat dalam berbagai aspek kehidupan suatu masyarakat, bangsa dan negara . Dimana berbagai aspek - aspek kehidupan Ekonomi, Pendidikan, Budaya, Kesejahteraan, Kesehatan, Hukum dan Keadilan, Keamanan dan kekuatan angkatan bersenjata mencapai puncak kemandirian, kuat dan terdepan.

Bagaimana suatu masyarakat, bangsa dan negara bisa mencapai keunggulan berbagai aspek kehidupan tersebut di atas salah satu indikator yang menjadi fokus pembangunan dan pengembangan adalah mempersiapkan manusianya.

Salah satu cara mempersiapkan manusia masa depan adalah dengan memperhatikan secara fokus dan serius pada sisi pemberdayaan perempuan dan keluarga.

Dalam hal ini Kaum perempuan, Karena Perilaku Kaum Wanita bisa menjadi indikator atau tolak ukur Kemajuan, Peradaban Suatu bangsa

Kemudian bagaimana mewujudkan suatu bangsa itu Kuat, Maju. Beradab dan Unggul dalam dunia sekarang ini dengan kemandirian ekonomi Islam (Syariah) di sektor Mikro berbasis wanita dan keluarga. 


\section{B. PERMASALAHAN}

Keluarga merupakan pelaku ekonomi pada taraf yang yang paling mikro, oleh karena itu dasar ketahanan ekonomi suatu negara dapat di lihat bagaimana tingkat kemakmuran dan kesejahteraan masyarakat terkecil yaitu keluarga. jika setiap keluarga di Indonesia bisa mencapai kesejahteraan yang baik maka dalam sekala yang lebih luas dapat menjadi pilar ekonomi masyarakat wilayah, daerah sampai pada akhirnya nasional, jika ini secara berjenjang dapat di capai maka akan terjadi ketahanan ekonomi nasional yang kuat.

Oleh karena itu menjadi hal yang sangat penting dan strategis bagaimana masyarakat dengan berbasis keluarga ini dapat membangun kemandirian, utama nya dalam mengelola keuangan keluarga sehingga dapat meningkatkan kualitas kehidupan dalam hal ini kesejahteraan dan kemandirian

Bagaimana mengetahui peran dan kontribusi pemberdayaan perempuan dan keluarga, sehingga mampu menjawab permasalahan yang secara umum terjadi pada masyarakat kita khususnya para pelaku bisnis usaha kecil dan menengah berbasis ekonomi bersyariah.

1. Apakah pemberdayaan perempuan dan keluarga mampu menjangkau seluruh lapisan masyarakat (networking) sebagai pelaku bisnis UKM berbasis syariah

2. Apakah sebagai lembaga keuangan Mikro BMT memahami pola dan keterampilan bisnis UKM berbasis syariah

3. Apakah dengan pemberdayaan perempuan dan keluarga dalam UKM berbasis syariah secara efektif dan efisien mencapai pertumbuhan yang optimal.

\section{ANALISA DAN KESIMPULAN}

1. Hal-Hal utama yang harus dilakukan dalam membangun pemberdayaan perempuan dan keluarga sehingga dapat secara mental dan keterampilan berkontribusi dalam sektor mikro ekonomi syariah adalah:

memahamkan kepada kaum ibu dan perempuan akan pentingnya memahami tujuan dalam berekonomi syariah, yakni : maqosid syariah ekonomi.

Aqidah, adalah ketetapan hati yang tidak ada keraguan di dalamnya. Kidah merupakan fungsi utama dalam ekonomi islam. Contoh: dalam bentuk keyakinan 
kepada Allah, bahwa harta dalam islam adalah amanah yang diberikan oleh Allah, sebagai pemilik mutlak kekayaan seluruh alam kepada manusia sebagai khalifatullah fil ard.

Syariah, adalah aturan-aturan yang telah ditetapkan oleh Allah SWT kepada hambahambanya yang ersumber dari al-quran dan as-sunnah. Syariah mencakup seluruh aspek kehidupanbaik ritual (ibadah) maupun sosial (muamalah). Ibadah berfungsi sebagai pengikat ketaatan dan keharmonisan hubungan antara manusia dengan Allah SWT, sedangkan muamalah berfungsi sebagai aturan hukum manusia yang ditetapkan oleh Allah untuk kemaslahatannya dimuka bumi.

Akhlak, merupakan komponen yang melekat selalu dalam diri manusia. Manusia diperintahkan oleh Allah SWT untuk melakukan kebaikan dimuka bumi, ini membuktikan pentingnya peran akhlak dalam kehidupan manusia.

Ketiga fondasi di atas harus menjadi satu keutuhan dalam implementasinya dikehidupan manusia yang direalisasikan kedalam fondasi ekonomi islam yang tediri dari falsafah dasar, yaitu:

Tauhid, merupakan asas utama dari segala aktivitas manusia. Sistem ekonomi yang telah dibangun oleh Rasulullah SWA adalah sistem yang menggabungkan harmonisasi dan persaudaraan (ukhuwwah dan tazkiyah) diantara umat manusia, disatukan oleh nilai-nilai tauhid yang berasal dari kata wahada yang berarti satu. Mereka adalah satu kesatuan umat yang berikrar tiada tuhan selain Allah, tiada yang maha kaya selain Allah, tiada yang maha berkuasa selain Allah dan tiada yang maha Adil selain Allah.

Sebagai pemakmur bumi (muamalah), dalam kewajiban ini direalisasikan menjadi kewajiban ekonomi, sosial, dan politik. Karenan itu manusia dipercaya untuk mengelola bumi, dengan kebebasan dalm bertindak untuk memilih yang benar dan meninggalkan yang salah karena manusia diberi pengetahuan untuk belajar. (AlAhzab:72)

Alam, tidak bisa dilepaskan dalam kehidupan manusia sebagai khalifah di muka bumi. Dalam alquran dijelaskan hubungan manusia dengan alam, yang meliputi alam kandungan, alam dunia, alam barzah dan alam akhirat. Alam dunia yang apling menentukan posisi manusia yang dimanifestasikan dalam perbuatan untuk mencapai kebahagiaan akhirat. Orang yang mengenal dirinya sendiri akan mengenal wujud dari alam (al-Zariyat, 19-20) 
2. Membangun Budaya / Perilaku

Hal-hal yang bersifat keinginan harus sesuai dengan Kebutuhan, Contoh :

Kebutuhan Dasar Rumah Tangga

Dalam memenuhi kebutuhan rumah tangga, harus benar-benar hemat, tepat manfaat, tidak mengadakan barang-barang yang hanya bersifat kebutuhan tambahan dan cadangan jika dibutuhkan.

Sikap ini sangat penting karena akan membuat cara berfikir yang efektif dan efisien, Kebutuhan Sarana / Fasilitas Rumah Tangga

Dalam memenuhi kebutuhan sarana fasilitas rumah tangga, seperti Kendaraan, alat komunikasi, perlengkapan-perlengkapan lainnya juga harus efektif dan efisien, misal; sarana kendaraan (mobil/motor) selain harus hemat bahan bakar, kendaraan juga yang memang mudah perawatan dan mudah jika di jual ketika akan memerlukan dana atau ganti kendaraan dengan yang lebih baru dan efisien, jadi tidak menumpuk/mengkoleksi kendaraan yang hanya menjadi pajangan dan di pakai sewaktu-waktu saja, karena itu akan menambah biaya dan pemborosan

Demikian hal-hal yang merupakan kebiasaan sehari-hari kita ubah pola tingkah dan perilaku kearah dari hanya sekedar angan-angan keinginan menjadi yang benar-benar sesuatu yang kita butuhkan.

Dalam memenuhi Kebutuhan harus bernilai Investasi, penguraikan point pertama di atas di mana kita harus merubah perilaku dalam memenuhi keinginan menjadi kebutuhan, selanjutnya adalah memastikan bagaimana kebutuhan itu harus bernilai investasi . contoh :

Dalam memenuhi kebutuhan dasar rumah tangga, agar kebutuha itu tidak hanya konsumtif tetapi juga harus bisa investmen, maka mulai lah dengan mengadakan barang dengan menghubungi produsen-produsen, ${ }^{1}$

Agar pembelian barang bisa jauh lebih murah, ketika harga perolehan murah maka volume pembelian di tingkatkan sehingga kita memiliki stok kebutuhan bahan pokok, Setelah itu hubungi komunitas yang kita aktif di dalam nya dan tawarkan jasa pengadaan barang dan seterusnya. Sehingga tercipta suatu pasar komunitas baru

${ }^{1}$ Sulistyani, Ambar Tegus. Kemitraan dan Model- Model Pemberdayaan. Yogyakarta: Gava Media, 2004. 
Demikian pula dengan kebutuhan lainnya, seperti pengadaan kendaraan, alat komunikasi dannsarana rumah tangga lainnya, harus bisa memberi nilai investasi baik jangka pendek maupun jangka panjang

3. Sikap selanjutnya adalah pola investasi harus terus inovatif dan Produktif, yaitu dengan melakukan :

- Memperkuat Branding/Merk, dalam pengadaan kebutuhan anggota komunitas sebaiknya membuat kemasan baru dengan merk yang tidak mewakili perusahan atau produsen lain. Dan terus di promosikan merk tersebut ke komunitas khususnya dan masyarakat pada umumnya agar tercipta banding baru yang terkesan mandiri.

- Mengumpulkan ide-ide komunitas dan konsumen

- Mengarahkan perkembangan produk dengan kebutuhan baru

- Mengukur efektifitas, lakukan evaluasi-evaluasi strategi dalam mengembangkan jaringan dan pemasaran

- Pemanfaatan sarana IT dalam memasarkan produk ${ }^{2}$

4.Tata kelola keuangan Komunitas

Ketika anggota komunitas sudah mulai produktif dan pasar sudah aktif maka perlu di adakan penghimpunan modal / asset kominitas.

Hal tersebut dapat dilakukan dengan mendirikan lembagai keuangan berbasis mikro seperti Baitul Maal Wattamwi (BMT)nyang berbadan hukum Koperasi Syariah dan beranggotakan kominitas yang rata-rata sudah menjadi pelaku bisnis mikro.

Adapaun teknis pendiriannya sebagaimana tang sudah di urai di bab sebelumnya ${ }^{3}$

${ }^{2}$ Irawan D Sudrajat. Konsep Dasar Keuangan Mikro. Pusat Inkubasi Bisnis dan Usaha Kecil /PINBUK 2009

3 Irawan D Sudrajat. Struktur Organisasi BMT. Pusat Inkubasi Bisnis dan Usaha Kecil/PINBUK 2009 


\section{DAFTAR PUSTAKA}

Iqbal Muhaimin , Syariah Ekonomi, Replubika Penerbit

Husein Umar, Manajemen Resiko Bisnis. Penerbit Gramedia Pustaka Utama

Irawan D Sudrajat. Konsep Dasar Keuangan Mikro. Pusat Inkubasi Bisnis dan Usaha Kecil /PINBUK 2009

Nurul Huda, Muhammad Haykal. Lembaga Keuangan Islam. Jakarta: Kencana, n.d.

Pusat Bahasa Departemen Pendidikan Nasional. Kamus Besar Bahasa Indonesia. Jakarta: Balai Pustaka, 2002.

Rahardjo, Dawam. Etika Ekonomi dan Manajemen. Yogyakarta: Tiara Wacana, 1990.

Soemitra, Andri. Bank dan Lembaga Keuangan Syariah. Jakarta: Kencana, 2014.

Sulistyani, Ambar Tegus. Kemitraan dan Model- Model Pemberdayaan. Yogyakarta: Gava Media, 2004.

Irawan D Sudrajat. Struktur Organisasi BMT. Pusat Inkubasi Bisnis dan Usaha Kecil/PINBUK 2009

Irawan D Sudrajat . Analisa Usaha . Pusat Inkubasi Bisnis dan Usaha Kecil/PINBUK 2009 